\title{
SEEDLING EMERGENCE OF PRIMED AND UNPRIMED TOMATO SEEDS AT DIFFERENT TEMPERATURE LEVELS
}

\author{
WAYAN SUENA \\ Department of Agroecotechnology, Faculty of Agriculture,Udayana University, \\ Denpasar, Bali, Indonesia 80232.
}

\begin{abstract}
ABSTRAK
Inisiasi perkecambahan benih tomat dengan perendaman dan tanpa perendaman benih pada tingkat suhu yang berbeda

Tujuan dari penelitian ini adalah; untuk mengetahui respon perlakuan perendaman biji terhadap perkecambahan benih tomat pada tingkat suhu tinggi dan rendah. Biji Joaquin dan Roma yang berkualitas, dinilai dari genotype yang tinggi, vigor rendah dan munculnya kecambah ditentukan setiap hari sampai kecambah memiliki satu sepasang daun yang membuka sempurna.

Kecambah memiliki perkembangan sepasang daun membutuhkan waktu 12-19 hari setelah masa perkecambahan. Hasil penelitian menunjukkan bahwa efek perlakuan perendaman terhadap berat kering kecambah yang paling menonjol pada perlakuan perendaman pada suhu $15^{\circ} \mathrm{C}$ dan $33^{\circ} \mathrm{C}$. Kecambah yang paling bagus tumbuh secara signifikan lebih cepat daripada kecambah pada perlakuan perendaman pada suhu $25^{\circ} \mathrm{C}$ yang ditunjukkan oleh kedua genotype.
\end{abstract}

\section{Kata kunci: perendaman, perkecambahan, biji tomat, suhu}

\section{INTRODUCTION}

The tomato (Solanum lycopersicum, syn. Lycopersicon lycopersicum \& Lycopersicon esculentum) is a herbaceous, usually sprawling plant in the Solanaceae or nightshade family that is typically cultivated for the purpose of harvesting its fruit for human consumption. Savory in flavor (and accordingly termed a vegetable), the fruit of most varieties ripens to a distinctive red color. Tomatoes are now eaten freely throughout the world, and their consumption is believed to benefit the heart among other things. They contain lycopene, one of the most powerful natural antioxidants (Anon., 2009b).
Temperature profoundly influences the growth of plants from germination to maturity. Seed germination rates are sensitive to both temperature and water potential. The times to germination of seeds imbibed at sub-optimal temperature and or reduced water potential are inversely proportional to the amounts by which temperature exceeds a base temperature and water potential exceeds a base water potential. Germination rates across a range of sub-optimal temperature and water potential can be normalized on the basis of the hydrothermal time accumulated in excess of these thresholds. However, seeds can also progress metabolically toward germination even at temperature or water 
potential too low to allow radicle emergence to occur. Seeds pre-imbibed at low water potential and dried back, or primed, germinate more rapidly upon subsequent re-imbibitions (Bradford and Haigh, 1994). It was known that the optimum temperature for germination of unprimed tomato seeds was between $25^{\circ} \mathrm{C}$ and $28^{\circ} \mathrm{C}$. Priming extended both the optimum range and the range over which germination was possible. According to Cheng and Bradford (1999) seed priming is use to break dormancy, speed germination, and improve uniformity of radical emergence. Priming technology can be applied to optimize the germination energy, uniformity and the germination capacity under non-optimal conditions, leading to a maximum stand under a range of conditions (Anon., 2009a). In the field the seeds must germinate in soil where imbibitions are influenced by the matrix potential and hydraulic conductivity of the soil (Shaykewich and Williams, 1971; Koller and Hadas, 1982). Expansion of the cells in the radicle and shoot depends initially on the properties and moisture of the soil and on atmospheric conditions when the shoot has emerged. Changes in the soil and air temperature will influence the physical properties of water in the soil but the major effect of temperature will be on metabolic processes. Respiration is reduced at temperatures below $20^{\circ} \mathrm{C}$ and above $35^{\circ} \mathrm{C}$. Cell division is inhibited at these temperatures and recently it has been demonstrated that cell wall elasticity and therefore cell expansion is reduced in grasses at low temperatures (Young, 1988). Consequently, seedling growth in the soil is a result of complex interactions between physical and physiological factors.

Plants can also be damaged by hot or cold temperatures. Young plants are very vulnerable to high temperature stress, because leaves and roots have not yet developed and the seedlings cannot regulate their water status or temperature (Basra et al., 1989). Survival during the germination phase may not necessarily mean that the seedling can survive and grow at the same temperature.

\section{METHODS}

Low and high vigor seed lots of the genotypes Joaquin (JQ) and Roma (RM) were used in this experiment. The seeds were primed with a solution of $\mathrm{K}_{2} \mathrm{HPO}_{4}$ $+\mathrm{KNO}_{3}(-1.0 \mathrm{MPa})$ at $15^{\circ} \mathrm{C}$ for eight days, and were then re-dried at $25^{\circ} \mathrm{C}$ for 48 hours.

Dry soil (25 g), with a sandy clay texture, was weighed into $30 \mathrm{ml}$ pots. Water plus fertilizer was watered onto soil until field capacity was reached. One seed was sown in each pot. Care was taken to ensure that all of the seeds were sown at a depth of $10 \mathrm{~mm}$. There were four pots (replicates) for every seed lot at each of three temperatures, $15^{\circ} \mathrm{C}, 25^{\circ} \mathrm{C}$ and $33^{\circ} \mathrm{C}$. The pots at each temperature were arranged in blocks which were randomized twice a day. To maintain the moisture during the experiment remain constant, a mist of water was applied twice a day.

The humidity was maintained at close to $100 \%$ by enclosing the pots in a plastic tent with small holes. The photon flux density inside the tent was $35-80 \mu$ mol m $\mathrm{m}^{-2} \mathrm{~s}^{-1}$. Photon flux densities in this range are recommended by the International Seed Testing Association (Ellis et al., 1986).

Seedling emergence (appearance of embryonic-axis at the surface of the soil) was determined daily until the seedlings were harvested. This occurred when at least $75 \%$ of the seedlings had one fully developed pair of leaves. The seedlings reached this requirement 19 days $\left(15^{\circ} \mathrm{C}\right.$ treatment) and 12 days $\left(25^{\circ} \mathrm{C}\right.$ and $33^{\circ} \mathrm{C}$ treatments) after sowing. After the 
seedlings were harvested, the roots were separated from the shoots. Soil was washed from the roots and both fractions were dried at $80^{\circ} \mathrm{C}$ for 24 hours. The roots and shoots then were weighed.

The priming response was calculated using the following equation:

$$
\frac{S D P-S D U}{S D U} \times 100 \%
$$

Where SDP = shoot dry weight of primed seeds, and SDU = shoot dry weight of unprimed seeds.

The effect of the treatments on maximum emergence, rate of emergence, prim-ability, and root and shoot dry weight was estimated by analysis of variance.

\section{RESULTS AND DISCUSSION}

Seedling emergence was fastest at $25^{\circ} \mathrm{C}$ for both seed lots of each genotype. Primed seed emerged faster than unprimed seeds at all three temperature levels. Maximum emergence percentage of both seed lots of each genotype (primed and unprimed) was unaffected by temperature (Table 1). Priming increased the rate of emergence and therefore the dry weight of tomato seedlings. This has been demonstrated previously by Alvarado et al., 1987. The effect of priming on seedling dry weight was most pronounced at $15^{\circ} \mathrm{C}$ and $33{ }^{\circ} \mathrm{C}$. These results indicate that the advantages of fast germination due to priming are sustained at least until the plant reaches the stage where leaves are fully developed. Seedlings from each treatment were harvested when they were at a similar stage of development, i.e., when $75 \%$ of the plants in that treatment had two fully developed leaves. Hence differences in seedling dry weight may have been caused by factors other than faster development. Ultimate crop growth is difficult to predict, however, the advantage of priming for field growing tomatoes appears to be mainly attributable to early seedling emergence (Barlow and Haigh, 1987).

Root and shoot dry weights of both seed lots of each genotype were lowest at $25^{\circ} \mathrm{C}$. The seedling were harvested when they were at the same developmental stage (first leaves fully developed) so that the effect of temperature treatments on growth could be readily compared. However, temperature had a profound effect on partitioning of dry weight between the stems leaves and roots and these largely accounted for the differences in dry weights. High vigor seed lots tended to have greater root and shoot dry weight than the low vigor seed lots. Priming increased the dry weight of both seed lots of each genotype.

The seedlings were taller at $15^{\circ} \mathrm{C}$ than at $25^{\circ} \mathrm{C}$ or $33^{\circ} \mathrm{C}$. Seedlings of primed seeds grew significantly faster than the seedlings of unprimed seeds of both high and low vigor seeds of each genotype. High vigor seeds were significantly taller than low vigor seeds up to two weeks after planting after which there was no difference. The maximum seedling height attained by all seed lots ranged from $1-6 \mathrm{~cm}$ 
Table 1. Maximum percentage of seedlings emergence at different temperature levels

\begin{tabular}{cccc}
\hline Temperature & Seed lots & \multicolumn{2}{c}{ Maximum seedling emergence (\%) } \\
\cline { 2 - 4 } & & Primed & Unprimed \\
\hline \multirow{2}{*}{$15^{\circ} \mathrm{C}$} & JQlv & $100 \mathrm{a}$ & $81.3 \mathrm{a}$ \\
& JQhv & $100 \mathrm{a}$ & $100 \mathrm{a}$ \\
& RMlv & $75 \mathrm{a}$ & $43.8 \mathrm{~b}$ \\
& RMhv & $100 \mathrm{a}$ & $100 \mathrm{a}$ \\
\hline \multirow{2}{*}{$25^{\circ} \mathrm{C}$} & JQlv & $81 \mathrm{a}$ & $75 \mathrm{a}$ \\
& JQhv & $100 \mathrm{a}$ & $100 \mathrm{a}$ \\
& RMlv & $81 \mathrm{a}$ & $75 \mathrm{a}$ \\
& RMhv & $100 \mathrm{a}$ & $100 \mathrm{a}$ \\
\hline \multirow{3}{*}{$33^{\circ} \mathrm{C}$} & JQlv & $75 \mathrm{ba}$ & $68 \mathrm{~b}$ \\
& JQhv & $93 \mathrm{a}$ & $93 \mathrm{a}$ \\
& RMlv & $75 \mathrm{ba}$ & $68 \mathrm{~b}$ \\
& RMhv & $100 \mathrm{a}$ & $93 \mathrm{a}$ \\
\hline
\end{tabular}

The figures followed by same letter both on the same column and rows within same growth temperature are not significantly different (Duncan's Multiple Range Test). Legend: JQ = Joaquin, $\mathrm{RM}=$ Roma; $\mathrm{lv}=$ low vigor, $\mathrm{hv}=$ high vigor .

The response to priming (based on shoot dry weight) varied with temperature. The minimum response to priming was at $25{ }^{\circ} \mathrm{C}$. At $15{ }^{\circ} \mathrm{C}$, low vigor seed lots of both genotypes tended to have greater priming response than high vigor seed lots. At $33{ }^{\circ} \mathrm{C}$, high vigor seeds had greater priming response. When the data for both low and high vigor seed lots were combined, it was clear that the largest response to priming was at sub and supra optimum temperatures.

Seeds emerged fastest at $25{ }^{\circ} \mathrm{C}$. However, it is difficult to interpret the data on the influence of temperature on dry weight because temperature had a large effect on partitioning between the stems, leaves and roots (more dry weight was partitioned to the stems at $15{ }^{\circ} \mathrm{C}$ and $33{ }^{\circ} \mathrm{C}$ than at $25{ }^{\circ} \mathrm{C}$ ). This should not affect the interpretation of the effect of temperature on primability, because temperature had a similar effect on partitioning in primed and unprimed seeds.
Priming response was greatest at $15^{\circ} \mathrm{C}$ and $33{ }^{\circ} \mathrm{C}$ as expected. However, low vigor seeds showed bigger response than high vigor seeds at the lower temperature, while high vigor seeds responded more at the higher temperature. These suggest that growth of low vigor seedlings is more sensitive to low temperatures, whereas growth of high vigor seedlings is more sensitive to high temperatures.

\section{CONCLUSION}

Priming increased the germination rate and emergence of seedlings in soil, particularly at sub and supra optimal temperatures. The advantage gained at the early stage of development was maintained and consequently seedling dry weight was greater. Vigor influenced prim-ability at low and high temperatures. The results indicate that priming may enhance growth and productivity of low and high vigor seeds in the field, with low vigor seeds benefiting more at low temperatures and 
high vigor seeds benefiting at high temperatures.

\section{AKNOWLEDGEMENT}

The author wish to thank the International Development Program (IDP) of Australian Universities and Collages for funding the research, as well as my supervisor Prof. Dr. EWR Barlow for his supervision, astute counsel and expertise during the research and complementation of my thesis. This is one part of my research project for the degree of Doctor of Philosophy at School of Biological Sciences, Macquarie University, Sydney, Australia.

\section{REFERENCES}

Alvarado, A.D., Bradford, K.J., and Hewitt, J.D. 1987. Osmotic priming of tomato seeds: effects on germination, field emergence, seedling growth, and fruit yield. J. Amer. Soc. Hort. Sci., 112(3), 427-432.

Anonym.2009a. Tomato seed priming. http://www.seedquest.com/t echnology/from/Incotec/tom atopriming/default.htm Accessed Nov.15 ${ }^{\text {th }}, 2009$.

Anonym.2009b.

Tomato.http://en.wikipedia. org/wiki/Tomato Retrieved November $16^{\text {th }}, 2009$.

Barlow, E.W.R. and Haigh, A.M. 1987. Effect of seed priming on the emergence, growth and yield of UC 82B tomatoes in the field.Acta Horticulturae, 200, 153164.

Bradford, K.J. and Haigh, A.M. 1994. Relationship between accumulated hydrothermal time during seed priming and subsequent seed germination rates.Published online by Cambridge University Press 19 Sep 2008.http://journals.cambrid ge.org/action/displayAbstra ct?fromPage $=$ onli... Retrieve d November $16^{\text {th }}, 2009$.

Cheng, Z. and Bradford, K.J. 1999. Seed priming. http://www.ingentaconnect. com/content/oup/exbotj/199 9/00000050/00000330/art00 089 Accessed Nov. $15^{\text {th }}$, 2009.

Ellis, R.H., Hong, T.D., and Roberts, E.H. 1986. Quantal response of seed germination in Brachiria humidicola, Echinochloa turnerana, Eragrostis tef and Panicum maximum to photon dose for the low energy reaction and the high irradiance reaction.J. Exp. Bot., 37, 742-753.

Koller, D. and Hadas, A. 1982.Water relations in the germination of seeds. In: Lange, O.L., Nobel, P.S., Osmond, C.B., and Ziegler, H. (eds.): Encyclopedia of plant physiology. New series. 12B, 401-431. SpringerVerlag, Berlin.

Shaykewich, C.F. and Williams, J. 1971. Resistance to water absorption in germination rape seed (Brassica napus L.).J. Exp. Bot., 22, 19-24.

Steiner, J.J., Grabe, D.F., and Tulo, M. 1989. Seed physiology, production, and technology.Single and 


$\begin{array}{lr}\begin{array}{l}\text { multiple vigor } \\ \text { predicting }\end{array} & \begin{array}{r}\text { tests for } \\ \text { seedling }\end{array} \\ \text { emergence } & \text { of } \\ \text { wheat.Crop.Sci., } & 29.782- \\ 786 . & \end{array}$

Young, S. 1988. Growth in a cold climate. Why does grass stop growing in winter?
Researchers in Wales are beginning to understand what happens to a plant's cells when the temperature falls. Their goal is to bread a forage grass that grows all year round. New Scientist, 44-48. 